\title{
PERANCANGAN APLIKASI PENILAIAN MAHASISWA BERPRESTASI UNIVERSITAS XYZ MENGGUNAKAN ALGORITMA K-MEANS CLUSTERING
}

\section{Lukman Hakim ${ }^{1}$}

${ }^{1}$ Program Studi Teknik Informatika, Fakultas Teknologi dan Desain, Universitas Bunda Mulia, Jakarta

\section{Article Info:}

Dikirim: 16 April 2019

Direvisi: 23 Mei 2019

Diterima: 24 Mei 2019

Tersedia Online: 29 Juni 2019

Penulis Korespondensi:

Lukman Hakim

Teknik Informatika Universitas

Bunda Mulia, Jakarta, Indonesia

Email:1hakim@bundamulia.ac.id,

\begin{abstract}
Abstrak: Sangat pentingnya prestasi mahasiswa perlu ditingkatkan untuk menunjang kinerja perguruan tinggi dalam pencapaian prestasi. Mahasiswa sebagai bagian insan akademik yang memiliki kecerdasan komprehensif yang harus di monitoring perkembangan softskill dan hardskill. Penelitian ini membuat aplikasi rekam jejak mahasiswa berprestasi dengan algoritma $K$ Means, Belum adanya rekaman jejak informasi mahasiswa berprestasi terintegrasi dengan departemen terkait menjadi kesulitan pada prodi untuk melakukan evaluasi setiap mahasiswa berpretasi, tujuan penelitian mengetahui sejauh mana algoritma k-means clustering dapat diterapkan untuk mengelompokkan mahasiswa berprestais menjadi 2 kategori yaitu berprestasi dan tidak berpretasi, hasil implementasi algoritma k-means 32\% mahasiswa berprestasi dan mahasiswa tidak berpresatsi 68\% berdasarkan 74 data mahasiswa secara random setiap angkatan dan akurat perhitungan $14 \%$..
\end{abstract}

Kata kunci: mahasiswa berprestasi; $k$-means clustering; kinerja.

\begin{abstract}
The importance of student achievement needs to be improved to support the performance of universities in achieving achievement. Students as part of academic people who have comprehensive intelligence that must be monitored the development of soft skills and skills. This study made the application of the track record of students performing with the K-Means algorithm. The absence of track record of information on students with integrated achievements with related departments became a difficulty for study programs for evaluating each student in a statement. students with partying become 2 categories, namely achievement and non-pretensions, the results of the implementation of the $k$-means algorithm $32 \%$ of students with achievement and non-statutory students are $68 \%$ based on 74 student data randomly each generation and accurate calculation of $14 \%$.
\end{abstract}

Keywords: student achievement; $k$-means clustering; performance. 


\section{PENDAHULUAN}

Menurut UU RI No. 20 Tahun 2003 tentang Sisdiknas Bab VI bagian ke empat pasal 19 bahwasanya “ mahasiswa "itu sebenarnya hanya sebutan akademis untuk siswa/ murid yang telah sampai pada jenjang pendidikan tertentu dalam masa pembelajarannya[1]. Menurut kamus besar bahasa Indonesia mahasiswa adalah orang yang belajar di perguruan tinggi[2]. Mahasiswa menurut Knopfemacher (dalam Suwono, 1978) adalah merupakan insan-insan calon sarjana yang dalam keterlibatannya dengan perguruan tinggi, dididik dan di harapkan menjadi calon-calon intelektual[3]. Mahasiswa generasi penerus bangsa serta sebagai ujung tombak generasi yang memiliki intelektual seperti para pendiri negara Indonesia yang lahir dari para mahasiswa yang memiliki kemampuan intelektual, Kritis, rasionalitas dalam membangun bangsa ini[4].

Pendidikan dan prestasi adalah dua hal yang tidak dapat dipisahkan dalam perguruan tinggi atau sekolah. Pendidikan di perguruan tinggi sama halnya dengan pendidikan di tingkat dasar yakni mementingkan prestasi setiap individu. Individu dapat dikatakan berprestasi apabila mampu bersaing menjadi yang terdepan di antara individu lainnya. Prestasi individu atau mahasiswa pada setiap Perguruan tinggi ditunjukkan dari nilai yang diberikan oleh dosen atau hasil studi setiap semesternya, Mahasiswa diharapkan memiliki kecerdasan komprehensif, yang tidak hanya didapatkan atau menekuni ilmu dalam bidangnya saja (hardskill), tetapi juga harus beraktivitas untuk mengembangkan softskills-nya[5]. Pengolahan data mahasiswa yang berprestasi untuk menentukan pemilihan mahasiswa tingkat kopertis dan nasional sangat dibutuhkan serta pemetaan mahasiswa berprestasi berdasarkan komponen penilaian seperti IPS, IPK dan Lomba Akademik atau non akademik, hal ini menjadi kesulitan tersendiri pada prodi, layanan kemahasiswa dalam menentukan mahasiswa berprestasi [6]. Namun tidak semua perguruan tinggi memiliki sistem rekap yang baik untuk memetakan mahasiswa berprestasi yang ingin mendelegasikan mahasiswa untuk berlomba tingkat regional, nasional atau lnternasional.

Berdasarkan permasalahan diatas perlu dibuatnya aplikasi pengolahan mahasiswa berprestasi dengan menggunakan algoritma k-means yang digunakan untuk menganalisa data dengan sistem partisi[7] dengan kmeans dapat memaksimalkan kesamaan data dalam satu klaster dan meminimalkan kesamaan data antar klaster[8], dengan pengolahan data mahasiswa secara terintegrasi antara pihak Kemahasiswa, Prodi dan pihak yang terkait untuk menghasilkan aplikasi mahasiswa berprestasi (e-mawapres).

\section{METODOLOGI PENELITIAN}

Penelitian ini memiliki beberapa tahapan untuk analisis, perancangan dan pengolahan data pada algoritma k-means sebagai berikut :

a. Tahapan pengumpulan data

Data yang dikumpulkan untuk mengetahui prestasi mahasiswa menggunakan data prodi teknik informatika universitas XYZ secara random.

b. Tahapan pengolahan data

Semua data mahasiswa prodi TI dilakukan berdasarkan variabel nilai IPK, IPS dan Prestasi Akademik dan

Non Akademik untuk proses berikut dilakukan clustering.

c. Analisis dan perancangan

Tahapan analisis menentukan kebutuhan fungsional dan non fungsional aplikasi yang akan dibangun dan perancangan menggunakan pemodelan UML terdiri dari usecase diagram, activity diagram, sequence diagram.

d. Tahap Clustering

Menentukan cluster untuk mahasiswa berprestasi berdasarkan indikator atau variabel yang sudah ditentukan. Pada tahapan ini menggunakan algoritma K-Means, berdasarkan data dapat dikelompokkan mahasiswa berprestasi dan mahasiswa tidak berprestasi.

\section{HASIL DAN PEMBAHASAN}

\subsection{Koding Algoritma K-Means di Implementasi Aplikasi E-Mawapres}

Proses cluster dimana $\$ \mathrm{x}==1$ adalah pada proses cluster pertama, dihitung nilai cluster dengan rumus euclidien distance dimana variabel untuk menyimpan nilai cluster adalah \$cluster1, \$cluster2. Setelah itu dicari nilai dengan jarak terkecil \$mincluster untuk membandingkan nilai cluster \$cluster1 dan \$cluster2. Nilai terkecil yang didapatkan, akan ditentukan posisi dari hasil cluster, jika nilai minimum pada \$cluster1 maka posisi pada cluster tersebut adalah posisi pertama atau 1, jika tidak posisi kedua atau 2 begitu dengan proses cluster selanjutnya. Gambar 1. dilihat pada listing program e-Mawapres. Koding implementasi K-Means mahasiswa berprestasi. 


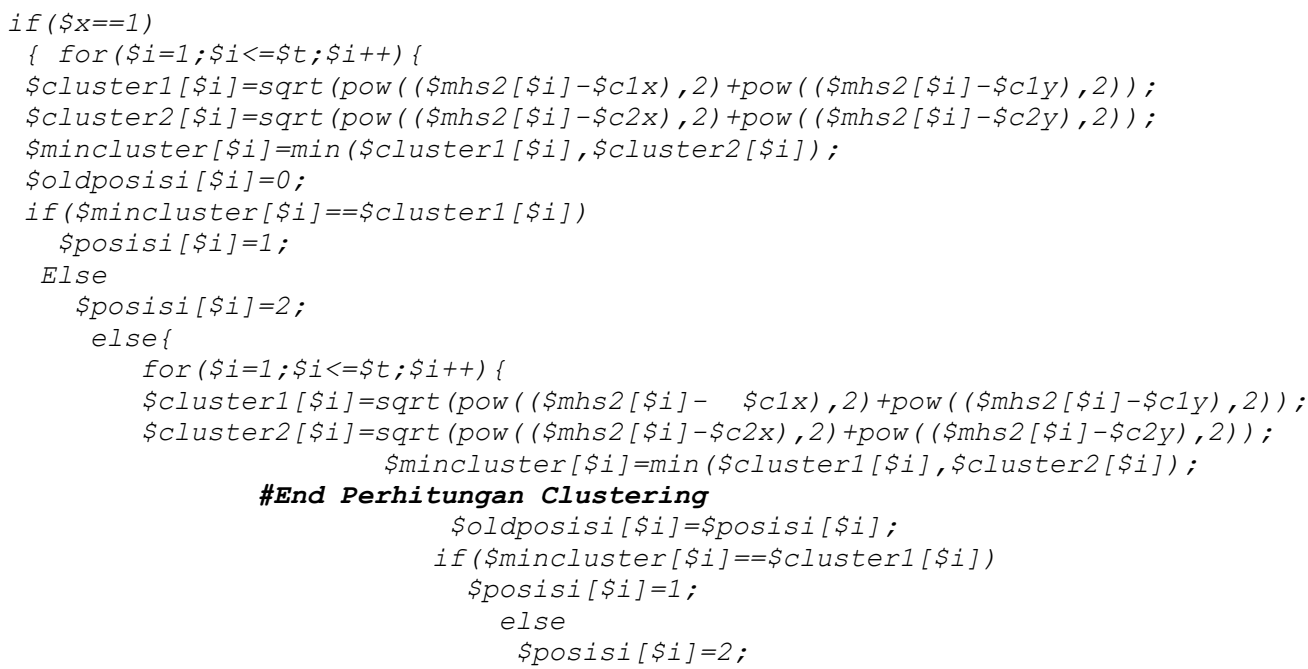

\section{Gambar 1. Koding Algoritma K-Means Clustering}

\subsection{Proses Clustering Menggunakan K-Means}

Berdasarkan data kompetensi mahasiswa yaitu prestasi akademik dan non akademik digunakan untuk melakukan proses clustering. Proses clustering dilakukan dengan cara menentukan titik cluster atau centroid setelah itu dihitung untuk mencari jarak dari setiap cluster, ketika jarak cluster telah ditemukan, hasil cluster dikelompokkan berdasarkan jarak dari setiap cluster tersebut. Apabila terdapat pemindahan titik dari cluster satu dengan cluster yang lain, maka dilakukan perhitungan cluster kembali sampai titik cluster tidak berubah. Dapat dilihat pada gambar 2. flowchar K-means Clustering mahasiswa berprestasi.

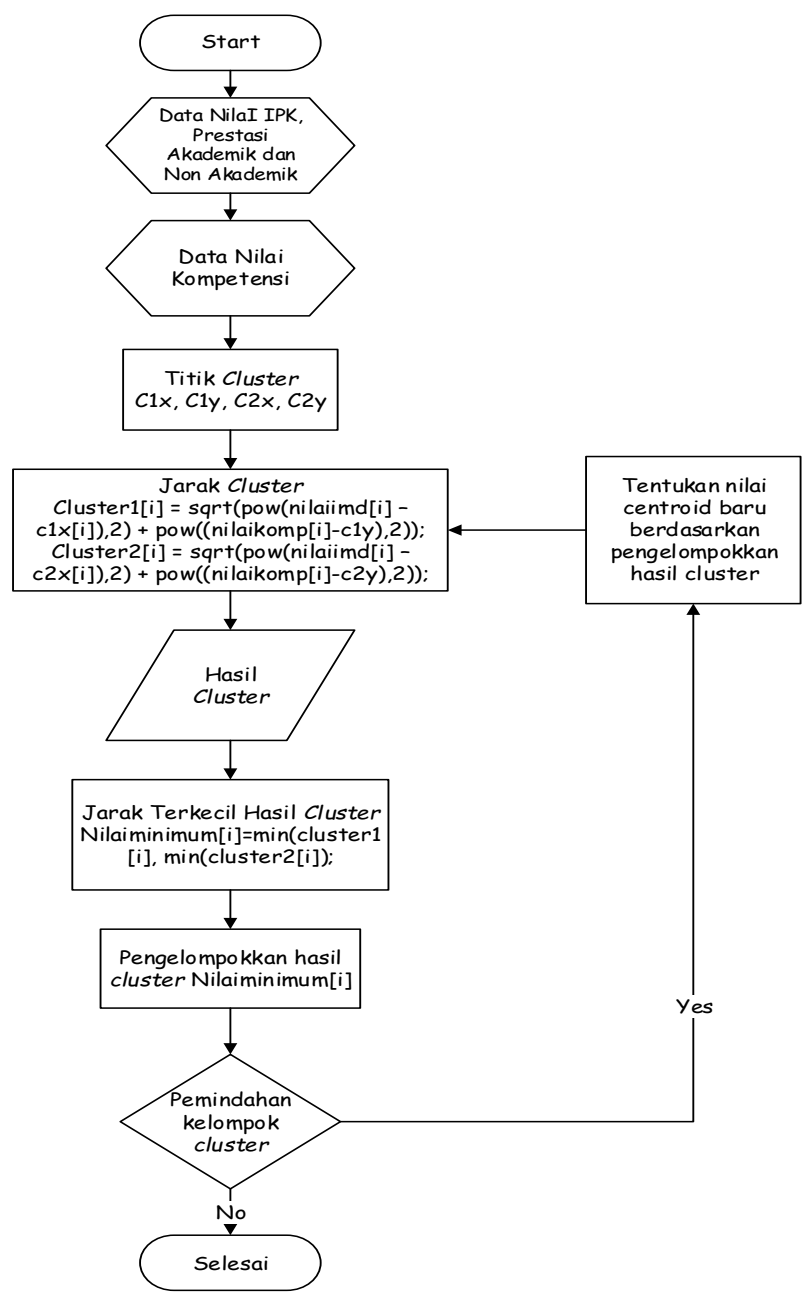

Gambar 2. Flowchar K-Means Mahasiswa Berprestasi 


\subsection{Perancangan Usecase Diagram e-Mawapres}

Pada diagram usecase menunjukkan hubungan aktivitas dengan aktor seperti bagian kemahasiswa, layanan mahasiswa dan prodi, dengan terintegrasi semua departemen yang terkait memberikan kemudahan dalam perekaman data mahasiswa berprestasi, bagian kemahasiswa mengolah data informasi prestasi non akademik, prodi memiliki informasi data prestasi akademik mahasiswa. Dapat dilihat pada gambar 3. Usecase diagram mawapres.

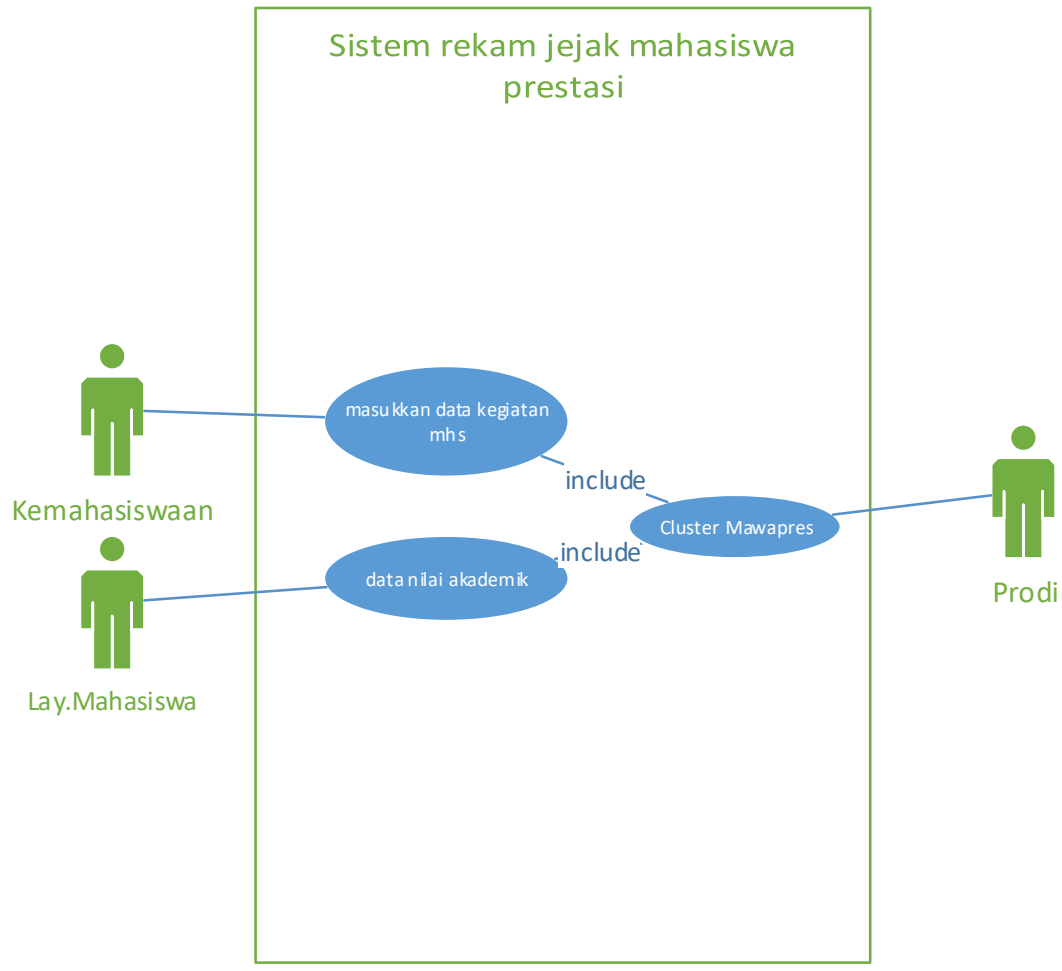

Gambar 3. Usecase Diagram e-Mawapres

\subsection{Perancangan Sequence Diagram e-Mawapres}

Keterhubungan antar objek kemahasiswa memberikan informasi prestasi, merekam kegiatan mahasiswa, dapat terekam pada objek prestasi, semua kegiatan prestasi mahasiswa dapat diketahui dengan prodi dan memberikan prodi informasi secara akurat terhadap prestasi keseluruhan mahasiswa. Dapat dilihat pada gambar 4. sequence diagram e-mawapres.

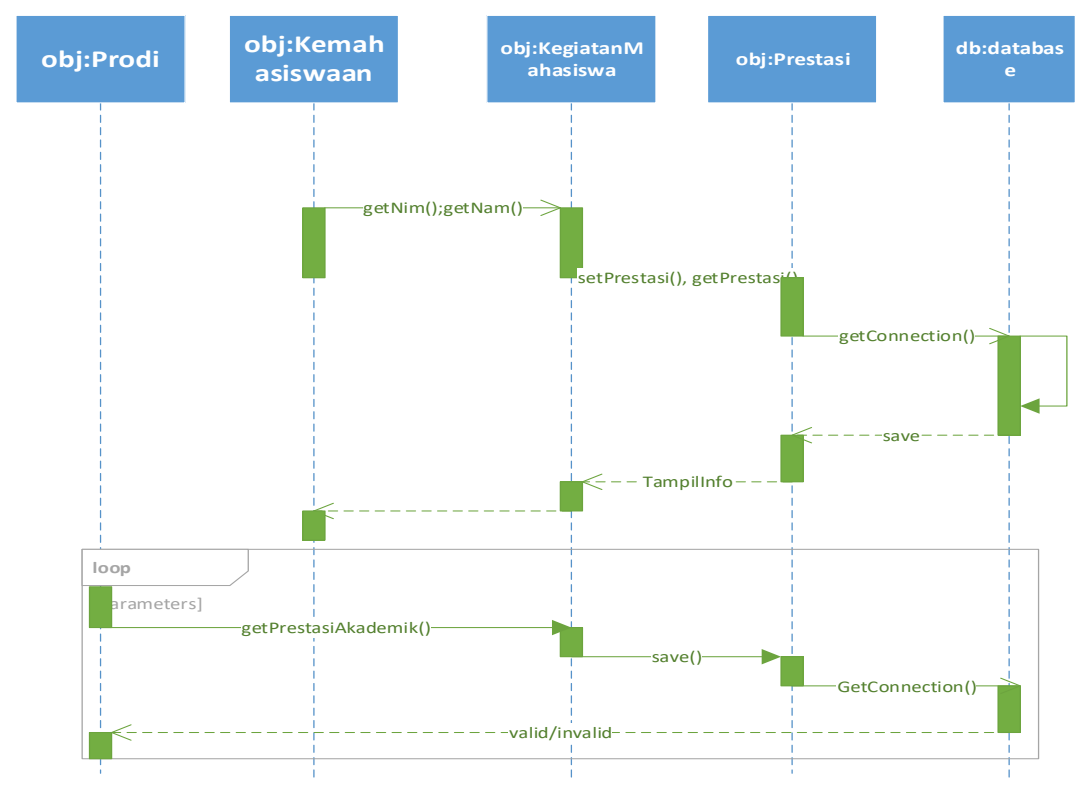

Gambar 4. Sequence Diagram e-Mawapres 


\subsection{Perancangan Activity Diagram e-Mawapres}

Pada diagram aktivitas menunjukkan hubungan antar aktor seperti prodi, kemahasiswa saling terintegrasi dalam melakukan rekam jejak mahasiswa yang berprestasi, dengan sistem seperti memberikan kemudahan pimpinan untuk mengetahui mahasiswa mana saja memiliki prestasi secara akademik dan no akademik. Untuk lebih jelasnya dapat dilihat pada gambar 5. activity diagram rekam jejak e-mawapres sebagai berikut.

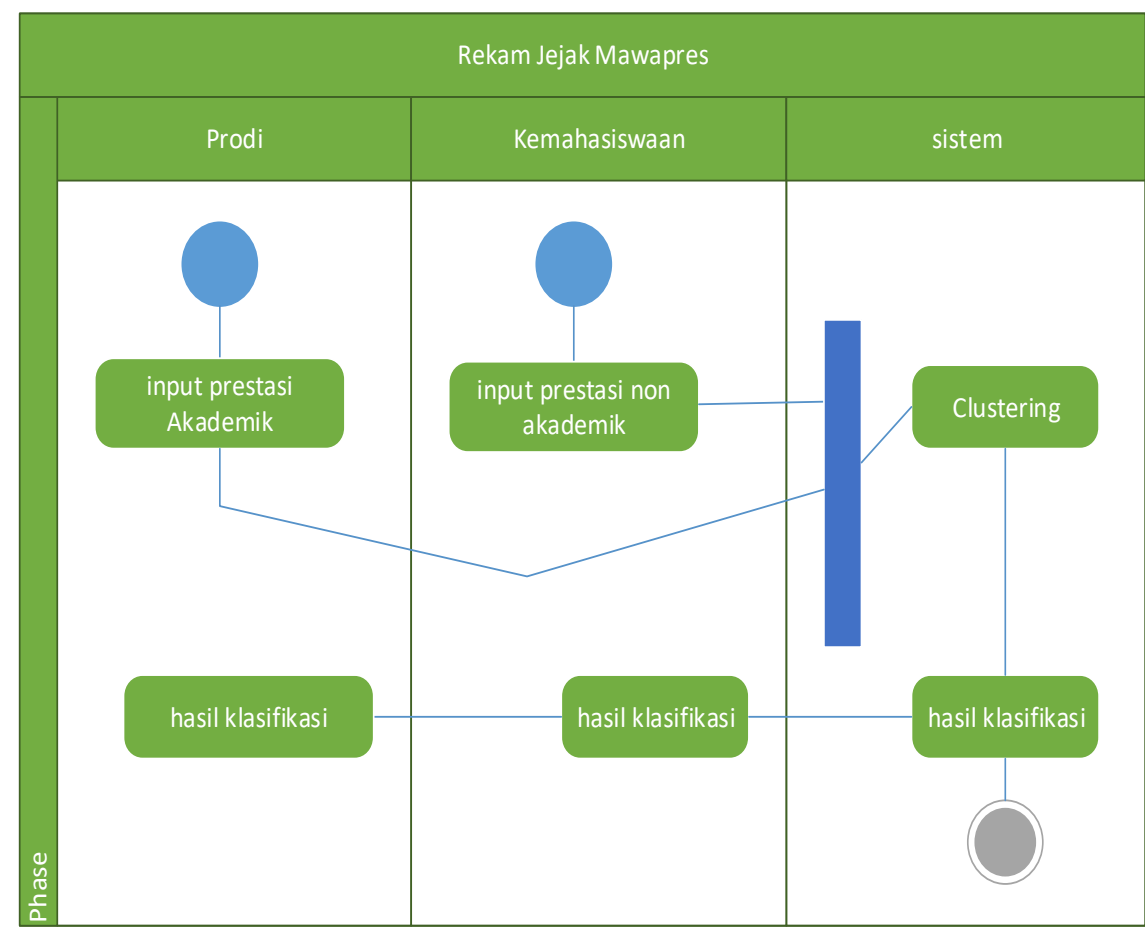

Gambar 5. Activity Diagram Rekam Jejak E-Mawapres

\subsection{Implementasi K-Means}

Untuk penentuan data mahasiswa universitas XYZ terbagi menjadi mahasiswa prestasi dan tidak prestasi. Untuk penentuan centroid dapat dilihat pada tabel 1. Berikut ini:

Tabel 1. Titik awal cluster

\begin{tabular}{cccc}
\hline Titik awal & Kategori & $\begin{array}{c}\text { Prestasi Akademik } \\
(\text { IPK) }\end{array}$ & $\begin{array}{c}\text { Prestasi Non akademik } \\
\text { (Lomba) }\end{array}$ \\
\hline Cluster 1 & Mahasiswa prestasi & 3,89 & 2.00 \\
Cluster 2 & Tidak prestasi & 2,33 & 1.00 \\
\hline
\end{tabular}

Hasil pengolahan data mahasiswa universitas XYZ yang secara random dari semua angkatan sebanyak 74 data, berdasarkan perhitungan berdasarkan tabel 1, cluster pertama yang memiliki jarak terkecil, untuk hasil perhitungan dapat dilihat tabel 2. Sebagai berikut .

Tabel 2. Perhitungan data mahasiswa untuk titik cluster

\begin{tabular}{|c|c|c|c|c|c|c|}
\hline \multirow{2}{*}{ No } & \multirow{2}{*}{ Nama Mahasiswa } & \multirow{2}{*}{$I P K$} & \multirow{2}{*}{ Prestasi } & \multicolumn{2}{|c|}{ Jarak } & \multirow{2}{*}{ Posisi } \\
\hline & & & & Cluster 1 & Cluster 2 & \\
\hline 1 & Herry Setiadi & 2,33 & 1 & 1,9 & 0,0 & $\mathrm{C} 2$ \\
\hline 2 & Anthony Veru & 2,38 & 1 & 1,8 & 0,0 & $\mathrm{C} 2$ \\
\hline 3 & Anthony & 2,41 & 1 & 1,8 & 0,1 & $\mathrm{C} 2$ \\
\hline 4 & Hadi & 3,48 & 2 & 0,4 & 1,5 & $\mathrm{C} 1$ \\
\hline 5 & joshua & 2,38 & 1 & 1,8 & 0,0 & $\mathrm{C} 2$ \\
\hline 6 & eric tomas & 3,01 & 1 & 1,8 & 0,0 & $\mathrm{C} 2$ \\
\hline 7 & Jati Kisworo & 3 & 1 & 1,3 & 0,7 & $\mathrm{C} 2$ \\
\hline 8 & Charlie Sandewo & 3,69 & 2 & 1,3 & 0,7 & $\mathrm{C} 2$ \\
\hline 9 & Septian & 2,78 & 1 & 0,2 & 1,7 & $\mathrm{C} 1$ \\
\hline 10 & Fabrian & 3,01 & 1 & 1,5 & 0,5 & $\mathrm{C} 2$ \\
\hline
\end{tabular}




\begin{tabular}{|c|c|c|c|c|c|c|}
\hline \multirow{2}{*}{ No } & \multirow{2}{*}{ Nama Mahasiswa } & \multirow{2}{*}{$I P K$} & \multirow{2}{*}{ Prestasi } & \multicolumn{2}{|c|}{ Jarak } & \multirow{2}{*}{ Posisi } \\
\hline & & & & Cluster 1 & Cluster 2 & \\
\hline 11 & Nico Phoan & 2,77 & 1 & 1,3 & 0,7 & $\mathrm{C} 2$ \\
\hline 12 & Ivan halim & 3,14 & 1 & 1,5 & 0,4 & $\mathrm{C} 2$ \\
\hline 13 & Daisy & 3,28 & 2 & 1,3 & 0,8 & $\mathrm{C} 2$ \\
\hline 14 & Shendy & 3,19 & 2 & 0,6 & 0,6 & $\mathrm{C} 1$ \\
\hline 15 & Saroinsong & 2,83 & 1 & 0,7 & 1,3 & $\mathrm{C} 1$ \\
\hline 16 & Daniel & 2,87 & 2 & 1,5 & 0,5 & $\mathrm{C} 2$ \\
\hline 17 & Ferdinand & 2,62 & 1 & 1,0 & 1,1 & $\mathrm{C} 1$ \\
\hline 18 & Yugha & 3,66 & 3 & 1,6 & 0,3 & $\mathrm{C} 2$ \\
\hline 19 & Eric k & 3,08 & 1 & 1,0 & 2,4 & $\mathrm{C} 1$ \\
\hline 20 & Yohannes & 3,24 & 2 & 1,3 & 0,8 & $\mathrm{C} 2$ \\
\hline 21 & Billy & 2,97 & 2 & 0,7 & 1,4 & $\mathrm{C} 1$ \\
\hline 22 & Steven & 3,12 & 1 & 0,9 & 1,2 & $\mathrm{C} 1$ \\
\hline 23 & Alvin & 3,43 & 2 & 1,3 & 0,8 & $\mathrm{C} 2$ \\
\hline 24 & Monica & 2,89 & 1 & 1,1 & 1,5 & $\mathrm{C} 1$ \\
\hline 25 & Eka P & 3,54 & 1 & 1,4 & 0,6 & $\mathrm{C} 2$ \\
\hline 26 & Regina & 3,23 & 1 & 1,1 & 1,2 & $\mathrm{C} 1$ \\
\hline 27 & Delvina & 3,06 & 2 & 1,2 & 0,9 & $\mathrm{C} 2$ \\
\hline 28 & Agus G & 2,82 & 3 & 0,8 & 1,2 & $\mathrm{C} 1$ \\
\hline 29 & Danny & 3,84 & 2 & 1,5 & 2,1 & $\mathrm{C} 1$ \\
\hline 30 & Rizal & 3,47 & 1 & 0,1 & 1,8 & $\mathrm{C} 1$ \\
\hline 31 & Ricky Tahma & 3,29 & 1 & 1,1 & 1,1 & $\mathrm{C} 1$ \\
\hline 32 & Cintya & 2,93 & 1 & 1,2 & 1,0 & $\mathrm{C} 2$ \\
\hline 33 & Erick M & 2,73 & 1 & 1,4 & 0,6 & $\mathrm{C} 2$ \\
\hline 34 & Lany & 3,97 & 2 & 1,5 & 0,4 & $\mathrm{C} 2$ \\
\hline 35 & Elvina & 3,94 & 2 & 0,1 & 1,9 & $\mathrm{C} 1$ \\
\hline 36 & Jessica & 3,76 & 1 & 0,0 & 1,9 & $\mathrm{C} 1$ \\
\hline 37 & Yessica Putri & 3,35 & 1 & 1,0 & 1,4 & $\mathrm{C} 1$ \\
\hline 38 & Tandi & 2,86 & 1 & 1,1 & 1,0 & $\mathrm{C} 2$ \\
\hline 39 & Ricko Noviandi & 2,74 & 1 & 1,4 & 0,5 & $\mathrm{C} 2$ \\
\hline 40 & Heri Susanto & 2,55 & 1 & 1,5 & 0,4 & $\mathrm{C} 2$ \\
\hline 41 & Samuel Dinata Wijaya & 2,88 & 1 & 1,7 & 0,2 & $\mathrm{C} 2$ \\
\hline 42 & Fedrik Lineker & 2,66 & 1 & 1,4 & 0,6 & $\mathrm{C} 2$ \\
\hline 43 & Valerian Hendri & 3,61 & 1 & 1,6 & 0,3 & $\mathrm{C} 2$ \\
\hline 44 & Sumana Dharmawan & 2,83 & 1 & 1,0 & 0,5 & $\mathrm{C} 2$ \\
\hline 45 & Williem & 2,78 & 1 & 1,5 & 0,5 & $\mathrm{C} 2$ \\
\hline 46 & Reshantio & 2,61 & 1 & 1,5 & 0,5 & $\mathrm{C} 2$ \\
\hline 47 & Hendraw Lijaya & 2,76 & 1 & 1,6 & 0,3 & $\mathrm{C} 2$ \\
\hline 48 & Agus Toni & 3,23 & 1 & 1,5 & 0,4 & $\mathrm{C} 2$ \\
\hline 49 & Tommy Ignatius Halim & 3,29 & 1 & 1,2 & 0,9 & $\mathrm{C} 2$ \\
\hline \multirow[t]{2}{*}{50} & Charli Habinsaran Tua & & & & & \\
\hline & Simbolon & 2,74 & 1 & 1,2 & 1,0 & $\mathrm{C} 2$ \\
\hline \multirow[t]{2}{*}{51} & Jonas Muara Batara Siregar & & & & & \\
\hline & & 2,55 & 1 & 1,5 & 0,4 & $\mathrm{C} 2$ \\
\hline \multirow[t]{2}{*}{52} & Suryawinata Marsudi & & & & & \\
\hline & Wijaya & 2,82 & 1 & 1,7 & 0,2 & $\mathrm{C} 2$ \\
\hline 53 & Ricky & 3,06 & 1 & 1,5 & 0,5 & $\mathrm{C} 2$ \\
\hline 54 & Evan Efendi & 3,05 & 2 & 1,3 & 0,7 & $\mathrm{C} 2$ \\
\hline 55 & Petrus Yonathan & 2,55 & 1 & 0,8 & 1,2 & $\mathrm{C} 1$ \\
\hline 56 & Agung Setiawan & 2,75 & 1 & 1,7 & 0,2 & $\mathrm{C} 2$ \\
\hline 57 & Stephen Louis & 2,93 & 1 & 1,5 & 0,4 & $\mathrm{C} 2$ \\
\hline \multirow[t]{2}{*}{58} & Nico Yunus Marselinus & & & & & \\
\hline & & 2,99 & 1 & 1,4 & 0,6 & $\mathrm{C} 2$ \\
\hline 59 & Albert Cahya Yojana & 2,6 & 2 & 1,3 & 0,7 & $\mathrm{C} 2$ \\
\hline 60 & Yogyawan & 3,27 & 1 & 1,3 & 1,0 & $\mathrm{C} 2$ \\
\hline 61 & Agus Susanto & 3,65 & 1 & 1,2 & 0,9 & $\mathrm{C} 2$ \\
\hline 62 & Antonio Houston & 3,41 & 1 & 1,0 & 1,3 & $\mathrm{C} 1$ \\
\hline 63 & Felix & 3,18 & 1 & 1,1 & 1,1 & $\mathrm{C} 2$ \\
\hline 64 & Ryzki Bachtiar Halim & 3,03 & 1 & 1,2 & 0,9 & $\mathrm{C} 2$ \\
\hline 65 & Arif Chendra & 2,9 & 1 & 1,3 & 0,7 & $\mathrm{C} 2$ \\
\hline 66 & Ricky Saputra & 3,05 & 1 & 1,4 & 0,6 & $\mathrm{C} 2$ \\
\hline
\end{tabular}


Jurnal SITECH, Vol 2, No 1, Juni 2019

$P-I S S N$ : 2615-8531, E-ISSN : 2622-2973

\begin{tabular}{|c|c|c|c|c|c|c|}
\hline \multirow{2}{*}{ No } & \multirow{2}{*}{ Nama Mahasiswa } & \multirow{2}{*}{ IPK } & \multirow{2}{*}{ Prestasi } & \multicolumn{2}{|c|}{ Jarak } & \multirow{2}{*}{ Posisi } \\
\hline & & & & Cluster 1 & Cluster 2 & \\
\hline 67 & Johan Purnama Putra & 2,75 & 1 & 1,3 & 0,7 & $\mathrm{C} 2$ \\
\hline 68 & Nugrah Salim & 3,64 & 1 & 1,5 & 0,4 & $\mathrm{C} 2$ \\
\hline 69 & Danield Lawrensha & 3,34 & 2 & 1,0 & 1,3 & $\mathrm{C} 1$ \\
\hline 70 & Lavinia Astria & 3,84 & 1 & 0,6 & 1,4 & $\mathrm{C} 1$ \\
\hline 71 & Reynald Henryleo & 2,92 & 1 & 1,0 & 1,5 & $\mathrm{C} 1$ \\
\hline 72 & Ricco Kristianto & 3,58 & 1 & 1,4 & 0,6 & $\mathrm{C} 2$ \\
\hline 73 & Ferry Hermawan & 3,53 & 1 & 1,0 & 1,3 & $\mathrm{C} 1$ \\
\hline 74 & Reycardo & 3,89 & 2 & 1,1 & 1,2 & $\mathrm{C} 1$ \\
\hline
\end{tabular}

\subsection{Pengujian K-Means Clustering}

Berdasarkan pengujian k-means clustering untuk mengetahui pengelompokkan mahasiswa berprestasi dan tidak berdasarkan hasil pengolahan centroid dan data riil dapat dilihat pada tabel 3. Sebagai berikut.

Tabel 3. Pengujian K-Means

\begin{tabular}{llc}
\hline Keterangan & Presentase (\%) & Akurasi Pengujian K-Means \\
\hline $\begin{array}{l}\text { Mhs berprestasi } \\
\text { (k-means) }\end{array}$ & $32 \%$ & $14 \%$ \\
Data riil & $19 \%$ & \\
Mhs Tidak & $68 \%$ & $14 \%$ \\
prestasi (k-means) & & \\
Data riil & $81 \%$ & \\
\hline
\end{tabular}

Berdasarkan tabel 3 pengujian menggunakan k-means sebanyak 74 data mahasiswa yang secara random setiap angkatan terbentuk klaster untuk mahasiswa berprestasi 32\% dan mahasiswa tidak berprestasi $68 \%$, dibandingkan dengan perhitungan data riil mahasiswa secara manual mahasiswa berprestasi $19 \%$ dan tidak berprestasi $81 \%$, untuk mencapai kategori mahasiswa berprestasi variabel IPK minimal 3.00 dan prestasi lomba minimal mengikuti dan dapat juara 1,2, atau 3.

\section{KESIMPULAN} berikut :

Berdasarkan penelitian mahasiswa berprestasi pada universitas XYZ, serta pengujian k-means clustering sebagai

a. Aplikasi e-mawapres memberikan kemudahan pada pimpinan perguruan tinggi untuk memudahkan dalam penentuan mahasiswa yang akan menerima beasiswa atau mengikuti kompetensi mahasiswa berprestasi.

b. Penggunaan Algoritma K-Means Clustering untuk menenentukan klaster mahasiswa berprestasi dan tidak berprestasi masih terjadi gap atau nilai akurat masing-masing 14\%, sedang untuk hasil perhitungan terbentuk klaster mahasiswa berprestasi $32 \%$ dan tidak berprestasi $68 \%$.

c. Hasil perhitungan k-means selalu berubah sesuai jumlah centroid.

\section{DAFTAR PUSTAKA}

[1] Nasional, S. P. (2003, Juli 8). UU No. 20 tahun 2003. Jakarta, Jakarta, Indonesia.

[2] KKBI, Kemendikbud.go.id.

[3] Suwono. 2014. Kenali pengertian Mahasiswa dan Menurut Para Ahli. http://www.pengertianku.net/2014/11/kenali-pengertian-mahasiswa-dan-menurut-para-ahli.html diakses (tgl 20 Mei 2019).

[4] RISTEKDIKTI. (2016). Pedoman pemilihan mahasiswa berprestasi program sarjana. Jakarta: Direktorat Jenderal Pembelajaran dan kemahasiswaan Kementerian Riset Teknologi dan Pendidikan Tinggi.

[5] Jazuli, A. (2012). Model Penentuan mahasiswa berprestasi dengan pendekatan logika Fuzzy. Jurnal Simetris , 115 .

[6] Nadia. (2017, Mei Sabtu). faktor-yang-mempengaruhi-prestasi-mahasiswa. Retrieved September Jumat, 2018, from SerambiNews: http://aceh.tribunnews.com.

[7] Informatikalogi. (2018, April 19). Algoritma K-Means Clustering. Retrieved April 21, 2019, from Informatikalogi.com: https://informatikalogi.com/algoritma-k-means-clustering/\#1. 
Jurnal SITECH, Vol 2, No 1, Juni 2019

$P-I S S N$ : 2615-8531, E-ISSN : 2622-2973

[8] Hakim, L., \& Seruni, H. (2018). Indikasi Penyimpangan Laporan keuangan akademik universitas XYZ menggunakan Algoritma Greedy dan K-Means. Jurnal Resti , 301-306. 